\title{
Analysis of Emission Reduction Effect for Rape Straw-poplar Biomass Pellet Fuel
}

\author{
Le-Ying ZHANG ${ }^{1, a}$, Yan LIU1,b, Yue ZHANG ${ }^{1, c}$ and Dian-Xiang ZHU 1,2,d,* \\ ${ }^{1}$ School of Intelligent Manufacturing, Taizhou Institute of Sci.\& Tech., NUST., Taizhou, China, \\ 225300 \\ 2Department of Wood Science and Technology, Nanjing Forestry University, Nanjing, China, \\ 210037 \\ ajoin9054@qq.com, b93867120@qq.com, ‘43827059@qq.com, ddianxiang@163.com \\ *Corresponding author
}

Keywords: Rape Straw, Biomass Pellet Fuel, Element Analysis, Technical Analysis; Emission Reduction.

\begin{abstract}
Rape plant is widely distributed in China, especially in southern China such as Xinghua in Jiangsu province with abundant rape straw resource. According to the characteristics of the biomass resources in those areas, it is very suitable to replace the traditional direct incineration method by using the technology of rape straw - poplar biomass pellet fuel. In this paper, element analysis and technical analysis of rape straw - poplar biomass pellet fuel were carried out. Combined with data, the effect of emission reduction is analyzed. Finally, it is concluded that the rape straw poplar biomass pellet fuel is a suitable alternative energy for bituminous coal, which is cleaner and more environmentally friendly.
\end{abstract}

\section{Introduction}

\section{Background Materials of Biomass Pellet Fuel}

Biomass pellet fuel is a combination of various types of biomass which are dried and grinded to a certain size by specialized equipment under certain conditions of temperature, humidity and pressure to form a regular shape, dense granular fuel. Biomass energy is one of the world's greatest energy, besides coal, oil and natural gas. The main sources of raw biomass materials contains wood, cotton stalk, wheat straw, corn stalks, rice straw, rice hull particles and so on [1,2,3]. Among them, wheat straw, rice straw, corn straw, etc. mixed with wood are usually used in china currently while in foreign countries wood biomass is more often used.

Biomass fuel began in 1970s during America's energy shortages, raw material were mainly waste wood from furniture or paper factories as alternative energy instead of electricity, coal and fossil fuels. In 1988 the world's first straw-biomass burning power plant was established in Denmark. There are 130 straw power plants recently. Regenerated energy such as straw power accounts for national energy consumption in $24 \%$ above. For saving gas and oil and reducing $\mathrm{CO}_{2}$ and $\mathrm{SO}_{2}$ emissions, the United States strongly advocated the use of wood pellet fuel, and grant appropriate subsidies. In 2005, 368 million tons of wood fuel resources were provided for energy production in the United States. The use of wood fuel resources accounts for about $10 \%$ of the energy demand in the United States.

In 2008, led by the Nanjing Forestry University combined with several companies and universities, the largest biomass pellet fuel production line in china was developed with annual $2.0 \times 10^{5} \mathrm{t}$ fuel production. China proposed in the Medium and Long-Term Development Plan for Renewable Energy that by 2020 national annual utilization of biomass solid fuels would reach 5.0x107 $\mathrm{t}$ [4].

\section{The Development Background of Rape Straw}

China is the world's second-biggest oilseed rape grower. In 2013 rape planting area was up to about $7500000 \mathrm{hm}^{2}$, that was $20 \%$ to the area of total world [5,6]. Rape straw production is up to 32.14 
million tons every year. Various provinces and cities in China are widely cultivated rape, especially in southern China such as Xinghua in Jiangsu province.

Due to the light weight and more area covering of rape straw, and the demand of planting rice after rapeseed harvests and other reasons, incineration is the common way to deal with rape straw. With focus on crop straw burning issues, in recent years there have been a variety of straw energy dealing options, such as livestock raising, straw returning, fermentation of biogas, bio char or bio-oil and so on[2,3,7]. But there are still about $50 \%$ of straw not being fully utilized. Rape straw in China is very rich in resources with centralized distribution. Its energy utilization has the scale superiority, which is worth paying attention to and developing [7].

\section{Materials and Methods}

In this paper biomass pellet that is 30\% Rape straw mixed with $70 \%$ Poplar is studied. Elemental analysis and industry analysis were made. And the effect of emission reduction is analyzed comprehensively to provide the reference for the application of this pellet fuel. According to the literature [8] and our experience in the past, Poplar and rape straw content ratio is suggested to 7: 3 which is the best ratio combination so we can consume rape straw as much as possible and achieve the best combustion effect in the meantime.

\section{Elemental Analysis}

Test equipment is the German VarioIII Automatic Element Analyzer. Dynamic combustion method was used to determine the content of elements such as $\mathrm{C}$ and $\mathrm{S}$.

Under the high temperature of $1150^{\circ} \mathrm{C}$, the sample was oxidized in a combustion tube which was introduced into a high concentration of oxygen and helium gas, and the decomposition products were detected by thermal conductivity detector in a certain order.

\section{Technical Analysis}

The main content of the fuel technical analysis includes the analysis of the content of water, ash, volatile matter and fixed carbon. Instruments and facilities were used as follows: sartoriusBS224S electronic balance, DHG-C automatic computer dryer, temperature controllable muffle furnace, and micro plant shredder.

With Air dry method for determination of moisture content of biomass pellet fuel, weighed for small amount of biomass pellet fuel sample $(1 \pm 0.1 \mathrm{~g})$, put it into the dryer with a constant temperature of $10^{5} \pm 5^{\circ} \mathrm{C}$. After $1.5 \mathrm{~h}$ drying, took the dry dish out and covered with a stamp, weighed the sample after cooling to room temperature. Then put it into the dryer to check the desiccation, about half an hour at a time, until successive drying mass change was less than $0.001 \mathrm{~g}$. Equation (1) is to calculate the moisture content of particles:

$$
M_{a d}=\frac{m_{1}}{m} \times 100
$$

Where: Mad - Moisture content of air dried sample, \% ;

$m_{1}$ - Lose mass after sample drying, g;

$m$ - The mass of the air dried sample, g.

Ash content of biomass pellet fuel was determined by rapid ashing method. Took a small amount of biomass pellet fuel air dried samples ( $1 \pm 0.1 \mathrm{~g}$ ), uniformly spread it into the cupel pre-burned to constant mass. Then put the cupel into the muffle furnace heated to $815 \pm 10^{\circ} \mathrm{C}$. Removed the cupel after $40 \mathrm{~min}$, cooled it in the open air for $5 \mathrm{~min}$. Moved it to the dryer and weighed after cooling to room temperature. And then checked the ignition, $20 \mathrm{~min}$ at a time, until two successive drying mass change was less than $0.001 \mathrm{~g}$. Equation (2) is to calculate the ash content:

$$
A_{a d}=\frac{m_{2}}{m} \times 100
$$

Where: Aad - Ash content of air dried basis, \% ; 
$m_{2}$ - Mass of residue after burning, $\mathrm{g}$.

Weighed air dried biomass pellet fuel sample $(1 \pm 0.1 \mathrm{~g}$ ) with particle size less than $0.2 \mathrm{~mm}$, put it into a porcelain crucible pre-burned to a constant mass under the temperature of $900{ }^{\circ} \mathrm{C}$ with a lid. Spread the sample on the bottom of the crucible with the lid on. Put it into the muffle furnace under the temperature of $920^{\circ} \mathrm{C}$, closed the door. After 7 min heating under the temperature of $900{ }^{\circ} \mathrm{C}$, removed the crucible, cooled it in the open air for about $5 \mathrm{~min}$, and then put it back into the dryer cooling to room temperature. Equation (3) is to calculate the volatile matter content:

$$
V_{a d}=\frac{m_{3}}{m} \times 100-M_{a d}
$$

Where: $V_{a d}$ - The volatile content of the air dried sample, \% ;

$m_{3}$ - Loss of mass after heating and drying, g.

Based on the data of moisture, ash, volatile matter content, according to the Equation (4) calculation can get fixed carbon content of the sample.

$$
F C_{a d}=100-M_{a d}-A_{a d}-V_{a d}
$$

Where: FCad - Fixed carbon content of air dried base specimens, \% .

\section{Results and Discussion}

\section{Experimental Results and Discussion of Technical Analysis}

In order to avoid the influence of initial water content on volatile, fixed carbon and ash content, the data of technical analysis are converted to the data after drying in this paper. Table 1 results of technical analysis test for biomass pellet fuel and bituminous coal.

Table 1 Technical analysis test results of biomass pellet fuel (dry basis)

\begin{tabular}{lccc}
\hline \multirow{2}{*}{ Sample } & \multicolumn{3}{c}{ Technical analysis[\%] } \\
\cline { 2 - 4 } & Volatile matter & Fixed carbon & Ash \\
\hline Poplar & 78.69 & 15.68 & 5.63 \\
Rape Straw & 75.89 & 15.22 & 13.19 \\
Bituminous coal & 29.32 & 47.26 & 23.42 \\
\hline
\end{tabular}

Volatile matter is a combustible gas which generated from the heated fuel. The higher volatile content is, the easier the fuel is to catch fire and burnt out. It is an important parameter to judge the quality of fuel. As we can see from table 1, rape straw and poplar as well as biomass pellet fuel contain higher content of volatile matter compared with bituminous coal, which burn more easily. Fixed carbon is the residual fuel in the fuel after analysis of volatile components in fuel. In the later stage of combustion, fixed carbon is the main component of combustion. The higher the fixed carbon content, the longer the combustion time is. The carbon content of poplar and rape straw was significantly lower than that of bituminous coal. Therefore, in the actual combustion process there is less burn resistant for the biomass pellet fuel. Ash is the main impurity in fuel. The more the content of ash, the less combustible components are. So Calorific value will decrease, it will more difficult to catch fire and burn. At the same time the heating surface is easy to ash. According to the test data, it can be seen that the ash content of poplar particles is the lowest, only $5.63 \%$, followed by rape straw fuel. The ash content of coal is $23.42 \%$, much higher than that of Poplar and rape straw particles. 


\section{Biomass Pellet Fuel Emissions Analysis}

After burning coal in boiler, discharge a large amount of fly ash, slag, $\mathrm{SO}_{2}$ and $\mathrm{CO}_{2}$, fly ash. $\mathrm{SO}_{2}$ is the major air pollutants, Slag takes up a lot of land, and $\mathrm{SO}_{2}$ is a major greenhouse gas. The use of biomass pellet fuel can minimize the emissions of those substances, and it has very significant environmental benefits.

Wood processing residue (poplar) and rape straw which are raw materials in the production of biomass pellet fuel as the assessment object with class II bituminous coal (boiler representative coal) for comparison, the calculations of the main pollutant emissions of the boiler using biomass pellet fuel instead of coal are made respectively. Major pollution components of bituminous coal and biomass pellet fuel are shown in Table 2.

Table 2 The main pollution components of biomass pellet fuel and bituminous coal [\%]

\begin{tabular}{lccc}
\hline \multicolumn{1}{c}{ Fuel type } & Ash content $A_{a r}$ & Carbon content $C_{a r}$ & Sulfur content $S_{a r}$ \\
\hline Biomass pellet & & & \\
Poplar & 2.2 & 51.43 & 0.05 \\
Rape straw & 10.5 & 41.47 & 0.19 \\
Bituminous coal & 32.48 & 46.55 & 1.94 \\
\hline
\end{tabular}

According to table 2, the ash and sulfur contents of poplar and rape straw are much lower than that of bituminous coal, which indicates that biomass pellet fuel is a cleaner energy compared with conventional fossil fuels.

The chain type boiler is selected for comparison and analysis, which accounts for about $90 \%$ of the total boiler in the industrial enterprise. In the chain boiler, the fly ash ratio is $20 \%$, and the dust removal efficiency of the dust collector is $90 \%$. Due to the large investment in desulfurization equipment, high operating costs, so the general enterprise boiler is rarely installed flue gas desulfurization equipment, and this situation is difficult to change in the near future. The results of calculation of the amount of ash discharged from the boiler to the atmosphere are shown in table 3.

Table 3 Ash emission from boiler

\begin{tabular}{|c|c|c|c|c|c|c|c|c|}
\hline Fuel type & $\begin{array}{c}\text { Fuel } \\
B[\mathrm{t}]\end{array}$ & $\begin{array}{c}\text { Ash } \\
A_{a r} \\
{[\%]}\end{array}$ & $\begin{array}{l}\text { Correction } \\
\text { factor of } \\
\text { fuel particle } \\
\text { size }\end{array}$ & $\begin{array}{c}\text { Fly } \\
\text { ash } \\
\text { ratio }\end{array}$ & $\begin{array}{c}\text { Ash } \\
\text { removal } \\
\text { efficiency }\end{array}$ & $\begin{array}{c}\text { Fly ash } \\
\text { emission } \\
{[\mathrm{t}]}\end{array}$ & $\begin{array}{c}\text { Fly ash } \\
\text { emission } \\
\text { reduction } \\
\text { rate } \\
{[\%]} \\
\end{array}$ & $\begin{array}{c}\text { Fly ash } \\
\text { emission } \\
\text { reduction } \\
\text { [t] }\end{array}$ \\
\hline \multicolumn{9}{|l|}{ Biomass pellet } \\
\hline Poplar & 200000 & 2.2 & 0.25 & 0.2 & 0.9 & 24 & 98.3 & 1276 \\
\hline Rapes traw & 200000 & 10.5 & 0.25 & 0.2 & 0.9 & 104 & 92.0 & 1196 \\
\hline Coal & 200000 & 32.48 & 1 & 0.2 & 0.9 & 1300 & 0 & 0 \\
\hline
\end{tabular}

The results show that: the boiler burning 200 thousand tons of coal discharging 1300 tons fly ash (dust), while 200 thousand tons of biomass pellet fuel discharging only 24 tons (poplar combustion) or 104 tons (rape straw particles combustion) fly ash (dust) to the atmosphere with less emissions of 1276 tons or 1196 tons. Compared with the burning bituminous coal, the emission rate of fly ash (dust) in the combustion of biomass particles was 98.3\% and 92\%, respectively. The effect of fly ash (dust) emission reduction was very significant (reduction).

Slag boiler emissions calculations are shown in table 4: 
Table 4 Amount of emission of boiler slag

\begin{tabular}{lccccccc}
\hline Fuel type & Fuel B[t] & $\begin{array}{c}\text { Ash } \\
A_{a r}[\%]\end{array}$ & $\begin{array}{c}\text { Ash } \\
\text { gross } \\
\text { weight } \\
H[\mathrm{t}]\end{array}$ & $\begin{array}{c}\text { Fly ash } \\
\text { emission } \\
M[\mathrm{t}]\end{array}$ & $\begin{array}{c}\text { Slag } \\
\text { discharge } \\
N[\mathrm{t}]\end{array}$ & $\begin{array}{c}\text { Slag emission } \\
\text { reduction } \\
\text { rate } \\
{[\%]}\end{array}$ & $\begin{array}{c}\text { Slag emission } \\
\text { reduction } \\
{[\mathrm{t}]}\end{array}$ \\
\hline $\begin{array}{l}\text { Biomass pellet } \\
\text { Poplar }\end{array}$ & 200000 & 2.2 & 4400 & 24 & 4376 & 93.1 & 59384 \\
$\begin{array}{l}\text { Rape straw } \\
\text { Coal }\end{array}$ & 200000 & 10.5 & 21000 & 104 & 20696 & 67.5 & 42964 \\
\hline
\end{tabular}

These results can be drawn: The boiler burning 200 thousand tons of bituminous coal, slag amount to 64960 tons, while burning 200 thousand tons of biomass pellet fuel, slag emissions are only 4376 tons (poplar fuel particles combustion) or 20696 tons (rape straw particles combustion) with less emissions of 59284 tons and 42964 tons respectively. Compared with the burning bituminous coal, the slag emission reduction rate of burning biomass particles was $93.1 \%$ or $67.5 \%$. The effect of slag emission reduction was very significant. In addition, the slag produced by the combustion of biomass particles is rich in nutrient elements such as $\mathrm{N}, \mathrm{P}, \mathrm{K}$ and so on, so it is worthy to be used as a good fertilizer.

\section{Summary}

(1) Fixed carbon of rape straw and poplar are lower than that of bituminous coal, so the burnout time will be shortened in the actual combustion process. The calorific value is also lower since less burn resistant. Fixed carbon of rape straw is even lower than that of poplar, so it is necessary to use $30 \%$ rape straw plus $70 \%$ poplar ratio to achieve the best combustion effect.

(2) Since its volatile content is high and close to that of poplar, rape straw is more flammable than bituminous coal. Its ash content is slightly higher than poplar, but much lower than that of bituminous coal. The ash and fly ash produced in the combustion process are few, and the pollution to the environment is very small.

(3) The content of S element in rape straw - poplar particle fuel is much lower than that of bituminous coal. Compared with coal, it produces a significant reduction of $\mathrm{SO}_{2}$ and other harmful gases in the combustion process. The amount of fly ash and slag emissions are much lower than that of bituminous coal, and the slag of biomass pellet fuel can be used as a good fertilizer.

(4) Despite its slightly lower calorific value and shorter burnout time, the emission reduction effect of rape straw - poplar particle fuel is much superior to that of bituminous coal. Rape straw - poplar particle fuel is a kind of clean and environment-friendly energy.

\section{Acknowledgement}

I would like to extend my sincere gratitude to professor Dian-Xiang ZHU. His instructive advices and useful suggestions on my paper benefited me a lot. Thanks for his continuous support and encouragement during the writing of this paper.

\section{References}

[1] Jin-Jin SHI, Dian-Xiang ZHU, Yuan-Zheng ZHAO etal. , Structural design and parametric modeling of wood pellet dynamic screen based on UG, Proceedings of the International Conference on Materials for Renewable Energy \& Environment. (2013)213-217.

[2] Dong-Sheng GUO, Chun-Hong HUANG, Spatial and temporal distribution of crop straw resources in past 10 years in China and its use pattern, Southwest China Journal of Agricultural Sciences. 04(2016)948-954.

[3] Xi-Yan LOU, Jin-Ping DING, Present situation and application prospect of biomass energy, Agricultural Science and Engineering in China. 02(2017)12-14. 
[4] Dian-Xiang ZHU, Research and development of biomass pellet fuel line and its key manufacturing technology, Engineering Sciences.04(2014)13-16+44.

[5] Information on http://faostat3.fao.org/download/Q/QC/E

[6] Ministry of agriculture of the People's Republic of China, China Agriculture Yearbook, China Agriculture Press,Beijing,2014.

[7] Bei-Bei ZHANG, Ying MA etal. , Evaluation of biomass energy utilization potential of rape straw resources in China, Renewable Energy Resources.01(2017)126-134.

[8] Li-Na WEN, Qiong TAO etal. , Comparison of calorific value of agro-forestry biomass and optimal formula of tobacco stem-cornstalk briquette, Hunan Agricultural Sciences.01(2016)43-46.

[9] Dian-Xiang ZHU, Xylinite-a New Type of Energy with Great Potentiality, Forestry Machinery \& Woodworking Equipment. (2009)37-40.

[10]Qiang LIU, Dian-Xiang ZHU, Research on Processing Technology and Equipment of Biomass Pellet Fuel, Woodworking Machinery. 01(2012)31-34. 